\title{
Analisis Optimasi Waktu dan Biaya Dengan Metode Time Cost Trade Off pada Proyek Gudang Amunisi
}

\author{
Eko Arif Budianto ${ }^{1}$, Albert Eddy Husin ${ }^{1, *}$ \\ Program Studi Magister Teknik Sipil, Universitas Mercu Buana, Jakarta ${ }^{1}$ \\ Koresponden*,Email: albert_eddy@mercubuana.ac.id
}

\begin{tabular}{|c|c|c|}
\hline & Info Artikel & Abstract \\
\hline Diajukan & 04 Mei 2021 & Projects are efforts that mobilize available resources, which are organized to achieve certain \\
\hline Diperbaiki & 24 Juli 2021 & important goals, objectives and expectations and must be completed within a limited period of \\
\hline $\begin{array}{l}\text { Keywords: } \\
\text { Amunition }\end{array}$ & st Trade Off, Time, Cost, & $\begin{array}{l}\text { time according to the agreement. In a construction project there are three important things that } \\
\text { must be considered, namely matters regarding time, cost and quality. In general, construction } \\
\text { quality is a basic element that must be maintained so that it is always in accordance with the } \\
\text { plan. However, in reality there are often cost overruns as well as delays in implementation time. } \\
\text { The purpose of this research is to analyze cost and time optimization. The time cost trade off } \\
\text { method is one of the analytical methods that aims to speed up the time and cost of a project. } \\
\text { This scheduling acceleration aims to find out how much time and cost it will take to complete } \\
\text { the project according to the efficient and best plan target. With the time cost trade off method, } \\
\text { the ammunition warehouse project can optimize time by } 34.69 \% \text { and cost optimization to } \\
4.24 \% \text {. This research is useful in construction projects. }\end{array}$ \\
\hline
\end{tabular}

\begin{abstract}
Abstrak
Proyek merupakan upaya yang mengerahkan sumber daya yang tersedia, yang diorganisasikan untuk mencapai tujuan, sasaran dan harapan penting tertentu serta harus diselesaikan dalam jangka waktu terbatas sesuai dengan kesepakatan. Dalam suatu proyek konstruksi terdapat tiga hal penting yang harus diperhatikan yaitu hal mengenai waktu, biaya dan mutu. Pada umumnya, mutu konstruksi merupakan elemen dasar yang harus dijaga untuk senantiasa sesuai dengan perencanaan. Namun demikian, pada kenyataannya sering terjadi pembengkakan biaya sekaligus keterlambatan waktu pelaksanaan. Tujuan penelitian ini adalah untuk menganalisis optimasi biaya dan waktu. Metode time cost trade off merupakan salah satu metode analisa yang bertujuan untuk mempercepat waktu dan biaya pada suatu proyek. Percepatan penjadwalan ini bertujuan untuk mencari berapa waktu dan biaya yang diperlukan untuk menyelesaikan proyek sesuai dengan target rencana efisien dan terbaik. Dengan metode time cost trade off pada proyek gudang amunisi dapat mengoptimasi waktu $34,69 \%$ dan optimasi biaya $4,24 \%$. Penelitian ini bermanfaat pada proyek konstruksi.
\end{abstract}

Kata kunci: Time Cost Trade Off, Waktu, Biaya, Gudang Amunisi

\section{Pendahuluan}

Proyek merupakan upaya yang mengerahkan sumber daya yang tersedia, yang diorganisasikan untuk mencapai tujuan, sasaran dan harapan penting tertentu serta harus diselesaikan dalam jangka waktu terbatas sesuai dengan kesepakatan [1]. Dalam suatu proyek konstruksi terdapat tiga hal penting yang harus diperhatikan yaitu hal mengenai waktu, biaya dan mutu. Pada umumnya, mutu konstruksi merupakan elemen dasar yang harus dijaga untuk senantiasa sesuai dengan perencanaan. Namun demikian, pada kenyataannya sering terjadi pembengkakan biaya sekaligus keterlambatan waktu pelak-sanaan [2] [3]. Pada pelaksanaan konstruksi terkadang terjadi keter-lambatan, bahkan bisa dikatakan hampir $80 \%$ proyek mengalami keterlambatan. Keterlambatan tersebut biasanya disebabkan baik dari faktor cuaca, internal maupun ekternal [4] seperti terlambatnya pengiriman material, koordinasi yang lemah, pengawasan yang tidak memadai, dan lain-lain. Jika suatu proyek mengalami keterlambatan sudah bisa dipastikan proyek tersebut mengalami kemunduran waktu dalam penyelesaiannya sehingga dibutuhkan percepatan pelaksanaan proyek atau yang biasa disebut dengan akselerasi proyek. Percepatan pelaksanaan ini, tentunya mempunyai beberapa alasan, seperti menghindari cuaca yang mengakibatkan menurunnya produktivitas pekerja, permintaan dari owner, mengejar keterlambatan proyek, dan lain - lain. Pada penelitian ini akan membahas tentang keterlambatan pada pembangunan proyek gudang amunisi.

Pelaksanaan pembangunan gudang amunisi mengalami beberapa kendala khususnya pada pekerjaan beton (dinding, atap dan lantai) sehingga jika dilihat dilapangan diprediksi penyelesaian pembangunan gudang amunisi mengalami keterlambatan atau selesai tidak tepat waktu. Ada beberapa alternatif dapat dipakai untuk mem-percepat kegiatan proyek 
adalah dengan menambah jam kerja, menambah grup tukang, kerja shift, memperbanyak alat, merubah metode kerja, dan lain-lain. Pada penelitian ini alternatif yang dipakai adalah percepatan dengan menambah 5 jam kerja/hari atau lembur.

Dengan menambahnya jam kerja akan mengakibatkan biaya tambahan yang dikeluarkan serta mutu yang dihasilkan juga menjadi lebih baik. Selain itu lingkup pekerjaan yang akan dibahas pada penelitian ini hanya pada pekerjaan struktur beton (atap, dinding dan lantai). Untuk menganalisa pada percepatan waktu pelaksanaan pada penelitian ini menggunakan metode Time Cost Trade Off (TCTO) yaitu perhitungan untuk mengetahui sejauh mana durasi proyek dapat dipersingkat dengan adanya penambahan biaya, sehingga dapat diketahui percepatan pelaksanaan pekerjaan struktur beton (atap, dinding dan lantai) dengan biaya yang paling minimum. Pengendalian biaya harus memperhatikan faktor waktu [5], karena terdapat hubungan yang erat antara waktu penyelesaian proyek dengan biaya proyek yang bersangkutan. Sering terjadi suatu proyek harus diselesaikan lebih cepat daripada waktu normalnya. Dalam hal ini pimpinan proyek dihadapkan kepada masalah bagaimana mempercepat penyelesaian proyek dengan biaya yang minimal. Berkaitan dengan itu perlu dipelajari analisa pertukaran waktu dan biaya [6]. Ada 2 sistem penekanan dalam analisa Time Cost Trade Off yaitu system jalur kritis dan cut set. Tujuan dari penelitian ini adalah untuk menganalisis optimasi biaya dan waktu dengan menggunakan metode Time Cost Trade Off [7]. Metode Time Cost Trade Off merupakan salah satu metode analisa yang bertujuan untuk mempercepat waktu dan biaya pada suatu proyek. Percepatan penjadwalan ini bertujuan untuk mencari berapa waktu dan biaya yang diperlukan untuk menyelesaikan proyek sesuai dengan target rencana efisien dan terbaik [8]. Dalam penelitian ini menggunakan sistim jalur kritis. Peneliti mengharapkan hasil penelitian ini mendapatkan efisiensi dari segi biaya dan waktu pada pembangunan gudang amunisi. Kebaruan dari penelitian ini adalah dengan menggunakan metode Time Cost Trade Off yang merupakan metode yang digunakan untuk mengefisiensi kinerja dari segi waktu dan biaya pada saat pelaksanaan konstruksi, hampir $75 \%$ proyek konstruksi yang menerapkan Time Cost Trade Off mendapatkan waktu dan biaya yang efisien. Manfaat penelitian ini untuk pengetahuan adalah mengetahui cara melakukan percepatan proyek konstruksi, menghitung biaya setelah dilakukan percepatan pelaksanaan, memberikan informasi tentang waktu penyelesaian proyek konstruksi dengan penambahan jam kerja (lembur/penambahan jam optimum) dan mengetahui cara percepatan waktu dan biaya penyelesaian proyek yang optimal.

\section{Metode}

Metode pelaksanaan analisa yang dilakukan meliputi pengumpulan data proyek (RAB, Schedule), Menyusun network diagram, Menyusun jumlah sumber data (resource), menentukan penambahan jam kerja (lembur) dari data tersebut akan didapatkan hasil :

1. Durasi optimal dan biaya optimal akibat penambahan jam kerja (lembur),

2. Perbandingan durasi optimal dan biaya optimal akibat penambahan jam kerja. Gambar 1 merupakan alur penelitian dengan meng-gunakan metode Time Cost Trade Off [9]:

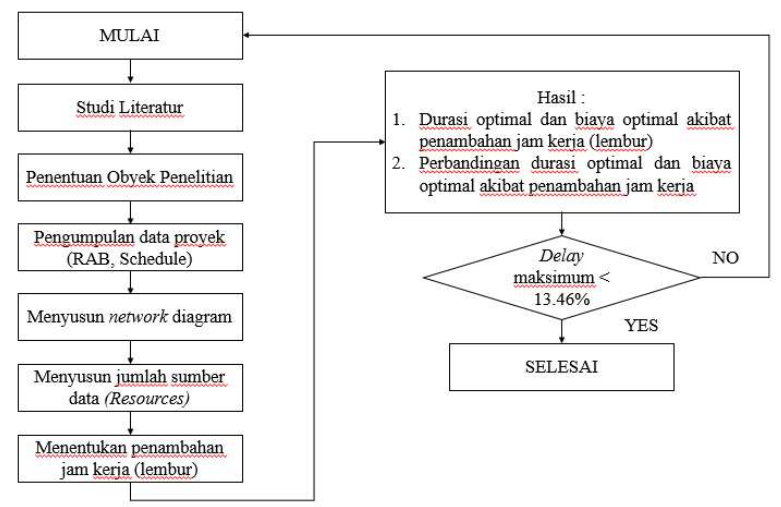

Gambar 1. Flow chart metode time cost trade off [10]

Adapun pekerjaan yang ditinjau dari penelitian ini adalah pekerjaan struktur beton (dinding, atap dan lantai). Diagram harus dilakukan dengan beberapa Langkah untuk menyusunnya antara lain [11]:

- Identifikasi lingkup proyek dan menguraikannya menjadi komponen-komponen kegiatan.

- Menyusun komponen-komponen kegiatan sesuai dengan urutan logika ketergantungan menjadi jaringan kerja.

- Memberikan perkiraan kurun waktu masing-masing pekerjaan.

- Identifikasi jalur kritis, float, dan kurun waktu penyelesaian proyek.

- Meningkatkan daya guna dan hasil guna pemakaian sumber daya.

Alternatif cara percepatan durasi pekerjaan [12]:

- Mengadakan shift pekerjaan.

- Menambah jam kerja atau waktu lembur.

- Menggunakan alat bantu yang lebih produktif.

- Menambah jumlah tenaga kerja.

- Mengunakan material yang lebih cepat pemasangannya.

- Menggunakan metode konstruksi yang lebih cepat. 
Terminologi Time Trade Cost Off

Pada proses perhitungan analisa pertukaran biaya dan waktu terdapat istilah - istilah yang digunakan, yaitu [13]:

a. Waktu Normal (Normal Time) adalah durasi yang diperlukan untuk melakukan kegiatan sampai selesai dengan cara yang efisien tetapi tidak mempertimbangkan adanya kerja lembur dan cara - cara khusus lainnya.

b. Waktu Percepatan (Crash Time) adalah durasi tersingkat untuk menyelesaikan suatu kegiatan yang secara teknis masih mungkin dengan asumsi bahwa ketersediaan sumber daya bukan merupakan hambatan.

c. Biaya Normal (Normal Cost) adalah biaya langsung tersingkat untuk menyelesaikan proyek dengan durasi normal.

d. Biaya Percepatan (Crash Cost) adalah biaya langsung yang diperlukan untuk menyelesaikan pekerjaan dengan durasi yang ter-singkat. Dengan melakukan penekanan waktu aktifitas, diusahakan agar pertambahan biaya yang ditimbulkan seminimal mungkin.

Disamping itu harus diperhatikan pula bahwa penekanannya hanya dilakukan pada aktifitas-aktifitas yang ada pada lintasan kritis. Selanjutnya langkah-langkah kompresi dapat dituliskan sebagai berikut [14]:

- Penyusunan jaringan kerja proyek dengan menuliskan cost slope dari masing-masing kegiatan. 2. Kompresi pada aktifitas yang berada pada lintasan kritis dan mempunyai cost slope terendah dengan menggunakan konstrain finish to start secara manual.

- Penyusunan kembali jaringan kerja proyek.

- Mengulangi langkah kedua, langkah kedua akan berhenti bila terjadi pertambahan lintasan kritis dan bila terdapat lebih dari satu lintasan kritis, maka langkah kedua di
- lakukan dengan serentak pada semua lintasan kritis dan perhitungan cost slope nya dijumlahkan.

- Menghentikan langkah kompresi bila terdapat salah satu lintasan kritis dimana aktivitas-aktivitasnya telah jenuh seluruhnya (tidak mungkin ditekan lagi) sehingga pengendalian biaya telah optimal.

Hubungan ketergantungan antar kegiatan dan durasi tiap kegiatan dapat disusun jaringan kerja dengan menggunakan bantuan software Microsoft Office Project 2016 [15] untuk melakukan perhitungan maju dan mundur.

Kegiatan dalam Precedence Diagram Method (PDM) digambarkan oleh sebuah lambang segi empat karena kegiatan ada di bagian Node atau sering juga disebut sebagai Activity On Node (AON) [16]. Kelebihan precedence diagram method dibandingkan dengan arrow diagram method yaitu:

1. PDM tidak memerlukan kegiatan fiktif/dummy sehingga pembuatan jaringan akan lebih sederhana

2. Hubungan overlapping yang berbeda dapat dibuat tanpa menambahkan jumlah kegiatan. Pada Gambar 2 merupakan PDM pekerjaan sruktur beton :

Berdasarkan perhitungan menggunakan metode CPM didapat pekerjaan pada jalur kritis yaitu pekerjaan struktur beton durasi awal untuk pekerjaan dinding beton : pekerjaan bekisting $=16$ hari, pekerjaan pembesian $=13$ hari, pekerjaan atap beton : pekerjaan bekisting 24 hari, pekerjaan pembesian 16 hari dan pekerjaan lantai beton : pekerjaan bekisting 11 hari, pekerjaan pembesian 9 hari, dengan total biaya sebesar Rp. 710.398.702,- untuk itu peneliti akan melakukan percepatan pekerjaan dengan pen-ambahan jam kerja (lembur) sebagai alternatif. Pada Gambar 2 akan terlihat jalur pekerjaan kritis yang akan ditinjau pada penelitian ini, yaitu pada pekerjaan struktur beton.

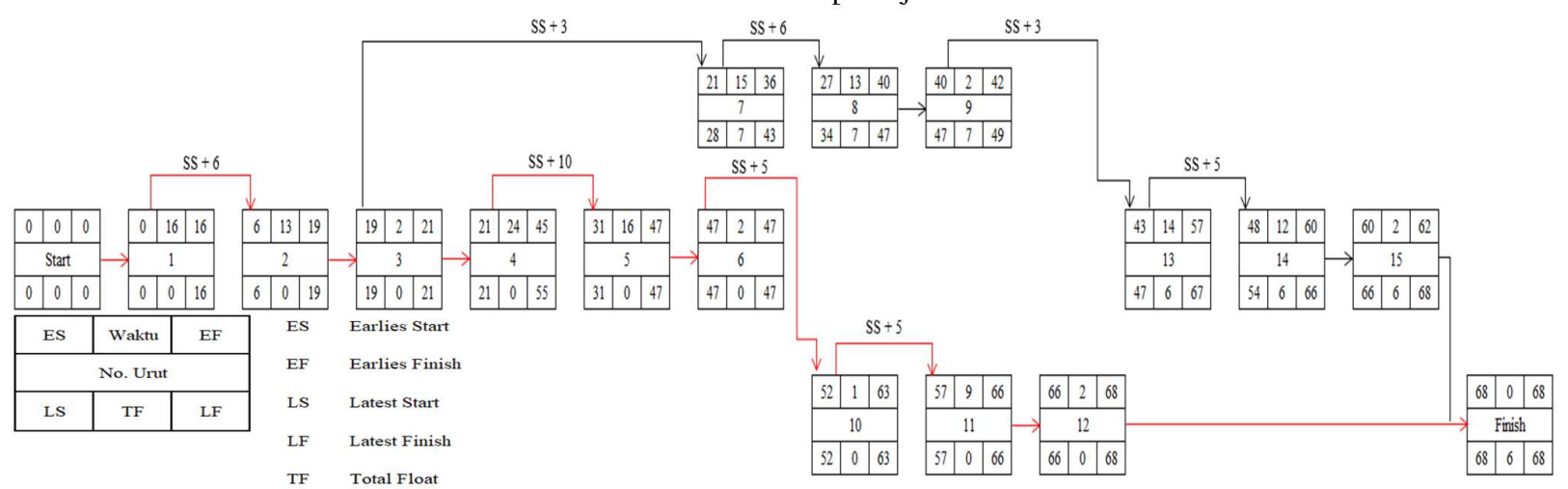

Gambar 2. PDM Pekerjaan Struktur Beton [17]

Hubungan antar kegiatan dalam metode ini ditunjukkan oleh buah garis penghubung yang dapat dimulai dari kegiatan kiri kekanan atau dari atas kebawah. Akan tetapi tidak dijumpai akhir garis penghubung ini di kiri oleh sebuah kegiatan.
Awal dan akhir kegiatan ini merupakan kegiatan fiktif yang dinamakan dengan START untuk kegiatan awal dan FINISH untuk kegiatan akhir. 
Setelah durasi dan ketergantungan untuk masing-masing kegiatan dimasukkan, maka akan diperoleh jaringan kerja berupa diagram preseden yang lengkap berisikan waktu mulai paling cepat (ES), waktu selesai paling awal (EF), waktu mulai paling lambat (LS), dan waktu selesai paling lambat (LF) dari satu kegiatan, untuk mengidentifikasi kegiatan kritis, float, dan waktu penyelesaian proyek. Dengan melihat diagram preseden dan total float dari masing-masing kegiatan dapat diketahui jalur kritis dan kegiatan-kegiatan kritisnya seperti pada Gambar 2.

Berdasarkan metode PDM yang terdapat jalur kritis untuk pekerjaan Struktur Beton adalah pekerjaan [18]:

- Pekerjaan membuat beton mutu f'c=26,4 MPa (K-300) membuat dinding beton vertikal.

- Pekerjaan membuat beton mutu f'c=26,4 MPa (K-300) membuat atap beton lengkung

- Pekerjaan membuat beton mutu f'c=26,4 MPa (K-300) membuat lantai beton elev.-0.500

\section{Hasil dan Pembahasan}

Setelah peneliti menentukan jalur kritis dengan PDM maka pekerjaan yang berada di jalur kritis sebagai berikut:

- Pekerjaan membuat beton mutu f'c=26,4 MPa (K-300) membuat dinding beton vertikal.

- Pekerjaan membuat beton mutu f'c=26,4 MPa (K-300) membuat atap beton lengkung

- Pekerjaan membuat beton mutu f'c=26,4 MPa (K-300) membuat lantai beton elev. -0.500

Maka dalam hal dilakukan penerapan dengan metode Time Cost Trade Off pada durasi waktu pekerjaan strukur beton. Proses analisa dilakukan dengan menggunakan bantuan software Microsoft Office Project 2016 maka didapatkan pekerjaan-pekerjaan yang masuk dalam jalur kritis atau lintasan kritis, yang mana pekerjaan-pekerjaan yang terdapat dalam jalur kritis akan dapat menimbulkan potensi keterlambatan apabila tidak di prediksi hal ini mengakibatkan keterlambatan penyelelesaian akhir proyek konstruksi dan dapat mengakibatkan pembengkakan biaya proyek konstruksi tersebut. Dengan Microsoft Office Project 2016 juga dapat membandingan antara schedule awal saat akan dimulainya proyek konstruksi dengan schedule crash yang dibuat untuk mempercepat waktu pelaksanaan proyek konstruksi hal ini sangat membantu team proyek untuk melakukan persiapan agar percepatan ini dapat dilakukan hal ini dapat terlihat pada Tabel 1 yaitu perbandingan schedulle awal dan schedulle crash.

Setelah dilakukan penerapan dengan metode Time Cost Trade Off maka dapat mengoptimasi waktu 34,69\% dengan rata-rata durasi percepatan optimum adalah 5 hari kerja dalam hal ini peneliti mengambil langkah dengan penambahan jam kerja (lembur). Pada Tabel 2 dijelaskan mengenai perbandingan antara biaya pekerjaan proyek konstruksi diawal dengan biaya pekerjaan proyek konstruksi setelah dilakukan penerapan metode Time Cost Trade Off.

Tabel 1. Perbandingan schedule awal dengan schedule crash

\begin{tabular}{cccc}
\hline No $\quad$ Item Pekerjaan & $\begin{array}{c}\text { Normal } \\
\text { Durasi }\end{array}$ & $\begin{array}{c}\text { Durasi } \\
\text { Hasil } \\
\text { Percepatan }\end{array}$ & $\begin{array}{c}\text { Percepatan } \\
\text { Durasi/Day }\end{array}$ \\
\hline
\end{tabular}

Pekerjaan Struktur Beton

1 Dinding Beton

$\begin{array}{lllll}\text { a Pekerjaan Bekisting } & 16 & 10 & 6\end{array}$

b Pekerjaan Pembesian $13 \quad 8 \quad 5$

2 Atap Beton

$\begin{array}{lllll}\text { a } & \text { Pekerjaan Bekisting } & 24 & 16 & 8\end{array}$

b Pekerjaan Pembesian $\quad 16 \quad 10 \quad 6$

3 Lantai Beton

$\begin{array}{lllll}\text { a } & \text { Pekerjaan Bekisting } & 11 & 7 & 4\end{array}$

b Pekerjaan Pembesian $\quad 9 \quad 6 \quad 3$

$\begin{array}{llll}\text { Total Jumlah } & 89 & 57 & 32\end{array}$

$\% \quad 34.69 \%$

Tabel 2. Perbandingan antara biaya schedule awal dan schedulle crash

\begin{tabular}{|c|c|c|c|c|}
\hline No & $\begin{array}{c}\text { Item } \\
\text { Pekerjaan }\end{array}$ & Normal Cost & Crash Cost & Cost Slope \\
\hline 1 & Dinding Beton & & & \\
\hline $\mathrm{a}$ & $\begin{array}{l}\text { Pekerjaan } \\
\text { Bekisting }\end{array}$ & Rp. 63.175 .000 & Rp. 75.175 .000 & Rp. 2.161.765 \\
\hline $\mathrm{b}$ & $\begin{array}{l}\text { Pekerjaan } \\
\text { Pembesian }\end{array}$ & Rp. 174.785.171 & Rp. 212.989 .252 & Rp. 8.470.588 \\
\hline 2 & Atap Beton & & & \\
\hline $\mathrm{a}$ & $\begin{array}{l}\text { Pekerjaan } \\
\text { Bekisting }\end{array}$ & Rp. 107.575 .100 & Rp. 135.309.694 & Rp. 3.330.882 \\
\hline $\mathrm{b}$ & $\begin{array}{l}\text { Pekerjaan } \\
\text { Pembesian }\end{array}$ & Rp. 284.135.539 & Rp. 346.829 .416 & Rp. 11.294.118 \\
\hline 3 & Lantai Beton & & & \\
\hline $\mathrm{a}$ & $\begin{array}{l}\text { Pekerjaan } \\
\text { Bekisting }\end{array}$ & Rp. 17.075.000 & Rp. 20.779 .082 & Rp. 970.588 \\
\hline $\mathrm{b}$ & $\begin{array}{l}\text { Pekerjaan } \\
\text { Pembesian }\end{array}$ & Rp. 63.652 .992 & Rp. 75.706 .564 & Rp. 3.860.294 \\
\hline
\end{tabular}

Setelah dilakukan penerapan metode Time Cost Trade Off untuk mempercepat pelaksnaan pekerjaan proyek konstruksi maka untuk meningkatkan efisiensi biaya pada pekerjaan 
proyek konstruksi dengan objek peneltian adalah proyek gudang amunisi dan hanya berfokus pada pekerjaan struktur beton maka peneliti mendapatkan optimasi biaya sebesar 4,24\% akan dijelaskan pada Tabel 6. Jadi dengan dilakukannya percepatan pekerjaan akan mendapatkan efisiensi dari segi waktu dan meningkatkan biaya pekerjaan struktur beton tersebut oleh sebab itu perlunya diterapkan metode Time Cost Trade Off. berikut akan dijelaskan tentang optimasi biaya dari percepatan waktu.

Tabel 3. Optimasi biaya percepatan waktu pada pekerjaan pembesian untuk mutu beton Fc' 26,4 Mpa (K-300)

\begin{tabular}{|c|c|c|c|c|}
\hline \multirow{2}{*}{ No } & \multirow{2}{*}{ Uraian } & \multicolumn{3}{|c|}{$\begin{array}{c}\text { Biaya pekerjaan pembesian setelah } \\
\text { optimasi }\end{array}$} \\
\hline & & Vol (kg) & $\begin{array}{l}\text { Harga } \\
\text { Satuan }\end{array}$ & Total \\
\hline 1 & $\begin{array}{l}\text { Membuat } \\
\text { dinding beton } \\
\text { vertical }\end{array}$ & 16.002 & Rp. 16.900 & Rp. 270.435 .832 \\
\hline 2 & $\begin{array}{l}\text { Membuat atap } \\
\text { beton } \\
\text { lengkung }\end{array}$ & 11.710 & Rp. 16.900 & Rp. 197.905.567 \\
\hline 3 & $\begin{array}{l}\text { Membuat } \\
\text { lantai beton } \\
\text { elv. } \pm 0,00\end{array}$ & 3.849 & Rp. 16.900 & Rp. 65.049.929 \\
\hline 4 & $\begin{array}{l}\text { Membuat } \\
\text { lantai beton } \\
\text { elv. }-0.500\end{array}$ & 751 & Rp. 16.900 & Rp. 12.695 .723 \\
\hline 5 & $\begin{array}{l}\text { Membuat plat } \\
\text { topi beton. }\end{array}$ & 80 & Rp. 16.900 & Rp. 1.348.667 \\
\hline \multicolumn{2}{|c|}{ Jumlah Besi } & & & Rp. 547.435.719 \\
\hline \multicolumn{2}{|c|}{ Total Besi } & & & Rp. 785.194 .757 \\
\hline
\end{tabular}

Tabel 4. Optimasi biaya percepatan waktu pada pekerjaan bekisting untuk mutu beton Fc' 26,4 Mpa (K-300)

\begin{tabular}{|c|c|c|c|c|}
\hline \multirow{2}{*}{ No } & \multirow{2}{*}{ Uraian } & \multicolumn{3}{|c|}{$\begin{array}{c}\text { Volume pekerjaan belisting setelah } \\
\text { optimasi }\end{array}$} \\
\hline & & $\begin{array}{l}\text { Vol } \\
\left(\mathrm{M}^{2}\right)\end{array}$ & $\begin{array}{l}\text { Harga } \\
\text { Satuan }\end{array}$ & Total \\
\hline 1 & $\begin{array}{l}\text { Membuat } \\
\text { dinding beton } \\
\text { vertical }\end{array}$ & 188.00 & Rp. 339.985 & Rp. 63.917.180 \\
\hline 2 & $\begin{array}{l}\text { Membuat atap } \\
\text { beton lengkung }\end{array}$ & 373.75 & Rp. 341.597 & Rp. 127.671.991 \\
\hline 3 & $\begin{array}{l}\text { Membuat lantai } \\
\text { beton elv. } \pm 0,00\end{array}$ & 109.67 & Rp. 186.466 & Rp. 20.449 .105 \\
\hline 4 & $\begin{array}{l}\text { Membuat lantai } \\
\text { beton elv. }-0.500\end{array}$ & 46.83 & Rp. 173.147 & Rp. 8.109.051 \\
\hline 5 & $\begin{array}{l}\text { Membuat plat } \\
\text { topi beton. }\end{array}$ & 1.17 & Rp. 208.197 & Rp. 242.897 \\
\hline \multicolumn{2}{|c|}{ Jumlah Bekisting } & & & Rp. 220.390 .223 \\
\hline \multicolumn{2}{|c|}{ Total Bekisting } & & & Rp. 382.055 .865 \\
\hline
\end{tabular}

Tabel 5. Optimasi biaya dari percepatan waktu pada pekerjaan pengecoran untuk mutu beton Fc' 26,4 Mpa (K-300)

\begin{tabular}{|c|c|c|c|c|}
\hline \multirow{2}{*}{ No } & \multirow{2}{*}{ Uraian } & \multicolumn{3}{|c|}{$\begin{array}{c}\text { Biaya pekerjaan pengecoran beton } \\
\text { setelah optimasi }\end{array}$} \\
\hline & & $\begin{array}{r}\text { Vol } \\
\left(\mathrm{M}^{3}\right)\end{array}$ & $\begin{array}{l}\text { Harga } \\
\text { Satuan }\end{array}$ & Total \\
\hline 1 & $\begin{array}{l}\text { Membuat dinding } \\
\text { beton vertical }\end{array}$ & 37.60 & Rp. 2.150 .000 & Rp. 80.840 .000 \\
\hline 2 & $\begin{array}{l}\text { Membuat atap } \\
\text { beton lengkung }\end{array}$ & 74.75 & Rp. 2.150 .000 & Rp. 160.712 .500 \\
\hline 3 & $\begin{array}{l}\text { Membuat lantai } \\
\text { beton elv. } \pm 0,00\end{array}$ & 32.90 & Rp. 2.150 .000 & Rp. 70.735 .000 \\
\hline 4 & $\begin{array}{l}\text { Membuat lantai } \\
\text { beton elv. }-0.500\end{array}$ & 14.05 & Rp. 2.150 .000 & Rp. 30.207 .500 \\
\hline 5 & $\begin{array}{l}\text { Membuat plat } \\
\text { topi beton. }\end{array}$ & 0.35 & Rp. 2.150 .000 & Rp. 752.500 \\
\hline \multicolumn{2}{|c|}{ Jumlah Beton } & & & Rp. 343.247 .500 \\
\hline \multicolumn{2}{|c|}{ Total Beton } & & & Rp. 508.281 .500 \\
\hline
\end{tabular}

Tabel 6. Optimasi biaya keseluruhan pekerjaan beton dengan mutu beton Fc' 26,4 Mpa (K-300)

\begin{tabular}{clc}
\hline No & Uraian & Jumlah Biaya \\
\hline 1 & Kontrak awal & Rp. 3.842.991.152,32 \\
2 & Ppn $10 \%$ & Rp. $384.229 .115,23$ \\
3 & Jumlah Total & Rp. 4.227.290.267,55 \\
4 & Dibulatkan & Rp. 4.227.290.000,00 \\
& Total optimasi pekerjaan besi, bekisting & \\
5 & dan cor beton mutu Fc' 26,4 Mpa (K- & Rp. 1.675.532.122,37 \\
& 300) & \\
6 & Selisih & Rp. $162.959 .568,66$ \\
7 & Optimasi & \\
\hline
\end{tabular}

\section{Kesimpulan}

Dari hasil analisis dan pembahasan dapat disimpulkan sebagai berikut:

1. Percepatan durasi proyek dengan metode Time Cost Trade Off dengan menambah jam kerja (Lembur), pada penelitian ini jalur kritis terdapat di pekerjaan struktur beton khususnya pekerjaan dinding beton, atap beton dan lantai beton.

2. Metode Time Cost Trade Off pada pembangunan gudang amunisi dapat mengoptimasi waktu sebesar 34,69\% dengan penambahan jam kerja sebanyak 5 jam per hari, dengan rata-rata durasi optimum adalah 5 hari.

3. Efisiensi biaya yang didapatkan dengan penerapan metode Time Cost Trade Off adalah 4,24\% yang didapatkan dari penghematan pemakaian material bekisting.

\section{Daftar Pustaka}

[1] Dipohusodo, Istimawan. Struktur Beton Bertulang. 
Gramedia Pustaka Utama. Jakarta. 1996.

[2] Praboyo, B. Keterlambatan Waktu Pelaksanaan Proyek: Klasifikasi dan Perangkat dari PenyebabPenyebabnya, Volume 1 no. 1 :49-58, Dimensi Teknik Sipil, Universitas Petra Surabaya. 1999.

[3] Tjaturono. Penerapan Produktivitas Tenaga Kerja Aktual dan modifikasi Penjadwalan dengan Metode Fast Track untuk Mereduksi Biaya dan Waktu Pembangunan Perumahan, Makalah Seminar REI Jatim, 16 Desember 2004, Hotel Sangri-La, Surabaya. 2004.

[4] R. Amalia, M. A. Rohman, and C. B. Nurcahyo, "Analisa Penyebab Keterlambatan Proyek Pembangunan Sidoarjo Town Square Menggunakan Metode Fault Tree Analysis ( FTA )," Inst. Teknol. Sepuluh Nopember, Surabaya, vol. 1, no. 1, pp. D20 D23, 2012.

[5] K. E. Leatemia, "Optimasi biaya dan durasi proyek menggunakan program Lindo ( studi kasus: pembangunan dermaga penyeberangan salakan tahap II )," J. Sipil Statik Vol.1 No.4, Maret 2013 ISSN 2337-6732 OPTIMASI, vol. 1, no. 4, pp. 226-232, 2013.

[6] "MICCE-Farida."

[7] K. El-Rayes and A. Kandil, "Time-Cost-Quality Trade-Off Analysis for Highway Construction," J. Constr. Eng. Manag., 2005, doi: 10.1061/(asce)07339364(2005)131:4(477).

[8] M. Priyo and A. Sumanto, "Analisis Percepatan Waktu Dan Biaya Proyek Konstruksi Dengan Penambahan Jam Kerja (Lembur) Menggunakan Metode Time Cost Trade Off: Studi Kasus Proyek Pembangunan Prasarana," 2016.

[9] A. E. Husin, "Time performance upgrade by critical chain project management and BIM 4D integration on top structural work of a high rise building construction project,” ARPN J. Eng. Appl. Sci., 2019.

[10] A. Aslam et al., "Analisa Time Cost Trade Off pada Proyek Pasar Sentral Gadang Malang,” vol. 4, no. 1, 2015.

[11] D. Arditi, O. B. Tokdemir, and K. Suh, "Challenges in Line-of-Balance Scheduling,” J. Constr. Eng. Manag., 2002, doi: 10.1061/(asce)0733-9364(2002) 128:6(545).

[12] A. Frederika, "Analisis Percepatan Pelaksanaan Dengan Menambah Jam Kerja Optimum Pada Proyek Konstruksi (Studi Kasus: Proyek Pembangunan Super Villa, Peti Tenget-Badung)," J. Ilm. Tek. Sipil, 2010.

[13] Soeharto, I. Manajemen Proyek dari Konseptual Sampai Operasional, Erlangga, Jakarta. 1997.

[14] R. Rama, D. Elga, A. Wibowo, and F. Kistiani, "Analisa Percepatan Proyek Metode Crash Program Studi Kasus: Proyek Pembangunan Gedung Mixed Use Sentraland," J. Karya Tek. Sipil, 2016.

[15] E. P. Information, "Microsoft Project 2007," Time, 2007.

[16] S. B. dan L. H. Safitri, Elfira, "Optimasi Penjadwalan Proyek menggunakan CPM dan PDM (Studi Kasus: Pembangunan Gedung Balai Nikah dan Manasik Haji KUA Kecamatan Kateman Kabupaten Indragiri Hilir)," Sains Mat. dan Stat., 2019.

[17] A. E. Husin and I. Siregar, "Multi-Span Bridge work based on line of balance and critical path methods integration in light rapid train," ARPN J. Eng. Appl. Sci., vol. 14, no. 17, pp. 3001-3012, 2019.

[18] A. E. Husin, F. Fahmi, S. Rahardjo, I. P. Siregar, and B. D. Kussumardianadewi, "M-PERT and lean construction integration on steel construction works of warehouse buildings," Int. J. Eng. Adv. Technol., vol. 8, no. 4, pp. 696-702, 2019, doi: 10.13140/RG.2.2. 19873.66402. 